\title{
1. State Engagement in the Handicraft Sector
}

Textual and material evidence shows that since the Shang dynasty (ca. sixteenth to eleventh century B.C.), workshops for manufacturing and construction existed. They provided weapons and objects for ceremonial and everyday use for the court and the ruling elite and planned and executed great central building projects like palaces, city walls, and funerary monuments. A great number of bronze vessels were produced for the ceremonial use of the rulers. Archeologists have calculated that it would have taken 18 years - if 10,000 earth pounders were engaged for 330 days per year - to complete the stamped-earth city walls of an early Shang city located in the vicinity of modern Zhengzhou in Henan. ${ }^{1}$ Both cases suggest that the work organization lay in the hands of specialized groups who could command great and, in the case of the bronze casters, highly skilled manpower. These workers and artisans most probably stood in the immediate service of the rulers and were supervised by their officials. ${ }^{2}$

Production and construction for the service of the state have been incorporated in various ways into the institutional frameworks of the ruling dynasties from that time onward. Between the third century B.C. and the tenth century A.D., government and civilian crafts and industries co-existed, and more state activist and more laissez-faire periods alternated in the longer dynasties of the Han and Tang. The short precursor dynasties Qin and Sui maintained a high degree of state activism, which was one of the reasons for their premature end.

The labour force especially for building, but also in the workshops, often had to serve the state in corvée obligations or in slavery, but the level of unfree labour apparently diminished after having reached its apex in the Northern and Southern Dynasties and the Sui. In 494 A.D., permanent work obligations were first reported to have been replaced by work shifts from the Liu-Song of the Southern Dynasties. ${ }^{3}$ The shift system was used time and again in subsequent dynasties until the first years of the Qing. A

1 Robert Bagley, 'Shang Archeology', p. 167. According to Bagley, the original length of the wall was about $7 \mathrm{~km}$, '[t]he overall thickness at the base is about $22 \mathrm{~m}$, and the greatest surviving height is $9 \mathrm{~m}$.'

2 David Keightley, 'The Shang: China's First Historical Dynasty', especially 'Dependant Labour', pp. 282-284.

3 Zhu Cishou, Zhongguo gudai gongye shi, p. 291. 
parallel trend consisted in the option to convert labour duty into monetary payment. ${ }^{4}$ These two trends often appeared simultaneously in the middle and late phases of dynasties. They suggest a more indirect and rational relationship between professional artisans and the state. The rise of the guilds as intermediaries between the government on the one hand and the artisan and merchant households on the other during the Tang period can also be interpreted in this light.

\section{Historical Overview: Official Crafts from the Song to the Ming}

In Chinese craft historiography, the transition from labour obligations for artisan households to a system of hired labour in the official sector between the fifteenth and seventeenth centuries is generally considered to be an important institutional and legal change. An overview of the methods of recruiting artisan labour for the dynasties and public work projects may show whether the break of the Qing government with previous practices was a radical rupture or can be understood as part of a more gradual process.

Marxist historiography in the tradition of the search of incipient capitalism in China assumes that dynastic economic policies created 'a closed and self-sufficient part of the feudal economy, which was ultimately incompatible with private handicraft industry'. ${ }^{5}$ How far does this characterization apply for the Song, Yuan, and Ming periods? When did the official and the civilian sector start to become mutually permeable, so that artisans could find employment in either of them? To answer these questions, the institutions, sizes of the artisan workforce, and the levels of coercion will be compared.

\section{The Song System, 960 to 1276}

For several reasons, the Song dynasty represents a major historical turning point in Chinese history. From the tenth century onwards, the bureaucratic state with an officialdom that was recruited in (theoretically) impartial and equal examinations among the free males prevailed until the end of the nineteenth century. The economy expanded and the population increased at an unprecedented rate, from around 55 million to 100 million from the 
mid-tenth to the late thirteenth century. ${ }^{6}$ Inventions such as the compass, porcelain, and gunpowder originate from this dynasty; and block printing and printing with movable types were developed commercially. The Song possessed a fully monetized commercial economy in which paper money was issued by the government in order to secure liquidity in the expanding commodity markets. Copper cash, the small denomination money for everyday use, was cast in amounts that were never again reached in Chinese history. ${ }^{7}$ However, on the military field, the Song gradually lost out to North Asian invaders. In 1126, a Jurchen tribe from northern Manchuria, which had assumed the dynastic name Jin, conquered the northern part of the Song empire and forced the rulers out of their capital Kaifeng. The Song established another, 'temporary' capital in Hangzhou/Lin'an south of the Yangzi delta and in 1142 officially ceded the northern part of their territory to the Jin. They ruled in the south until their ultimate defeat by the Mongols in 1276 .

Historians of China, and of the Song period in particular, in many respects see the Song as the apex of the Chinese bureaucratic state and of its cultural and economic achievements. ${ }^{8}$ But variant views have also been formulated. Kent Deng, for instance, comes to a quite negative evaluation of the economic and administrative performance of the Song government. He argues that the Song could not prevent large landholding and high rates of tenancy and had to finance an overpaid officialdom and an expensive military that was ultimately ineffective. Therefore, it profitably engaged in commercial activities. This trend, which had started in the Northern Song, intensified in the Southern Song when almost half of the territory and revenue sources were lost. Moreover, wealth was not spread evenly. Deng has hypothesized that migrational shifts - first south, out of the direct reach of the government of the Northern Song, and during the Southern Song probably back north towards the Jin territory - as well as uprisings in the Southern Song showed popular discontent with the strong emphasis on the market economy and the breaking away from agrarian traditions. ${ }^{9}$

6 Maddison, Chinese economic performance, pp. 24, 169.

7 The peak was 5 million strings of copper cash and 1.4 million strings of iron cash in the Yuanfeng era (978-1085), cf. Peng Xinwei, Monetary History, p. 438, n. 11. The highest average production figures reported in the Qing dynasty were at around 3.5 million per year between 1761 and 1765; see Burger, 'Minting during the Qianlong Period', p. 392.

8 Cf. e.g. John King Fairbank, China. A New History, pp. 88-107, 'China's Greatest Age: Northern and Southern Song'. See also the discussion in Maddison, Chinese economic performance, pp. 24-25 on various characterizations of Song growth and dynamism which Maddison believes to be exaggerated.

9 Kent Deng, Premodern Chinese Economy, pp. 301-310, 318-320. 
While judgments about the benefits of commercialization during the Song dynasty may vary, ${ }^{10}$ historians agree that state involvement in the non-agricultural part of the economy was intense and that the state sector surpassed the private economy. ${ }^{11}$ Craft products were bought up by the state at fixed prices. This was the so-called hemai system (acquisition by [mutual] agreement) that included a wide product range of textiles, porcelain, lacquers, and other luxury goods. Moreover, the provinces were required to deliver a fixed quota of manufactured and other commercial goods to the state as 'tribute'. State monopolies were handled either directly or through merchant intermediaries. ${ }^{12}$

\section{Scope and Size of the Official and Private Artisan Workforce}

Artisan labour was allocated by the state in two ways: the craftspeople could be employed (mujiang) on a long-term but not necessarily permanent basis; this system was also referred to as hegu (consensual employment). These persons formed the main force of the state workshops. 'Conscripted [people] from the guilds' (danghang) or 'artisans on shift' (fanjiang>) were summoned to fulfil labour duties for more ad hoc work. Over time, the Song guilds developed from instruments of state control to influential bodies of self-organization. ${ }^{13}$ Throughout the Song, they formed the interface between the individual artisan households and the state and were responsible for supplying labour to the government. For example, the guilds decided whose turn it was to serve the state in temporary work assignments.

There are no systematic overviews of the size of the workforce that the state could command. One estimate by Ju Qingyuan ${ }^{14}$ gives figures of 7,000 to 9,000 artisans in the armament manufactories of the central government, 18,000 ironsmiths in one military prefecture, and more than 10,000 workers in government mints (see Table 1). However, these calculations only show a fragment of the actual employment in government offices. Other

10 For a recent revision of the view that the Song state levied excessive taxes, see Liu Guanglin and Andrew Wareham, 'China and England Compared', p. 80.

11 Günter Lewin, Die ersten fünfzig Jahre der Song-Dynastie, p. 117.

12 Cf. Deng, Premodern Chinese Economy, p. 307 on changing state policies regarding monopolies. Salt, wine, and iron monopolies were given to merchants when they became less profitable, but the more profitable monopoly on imported medicines was permanently handled by the state.

13 Ju Qingyuan, Tō Sō kōgyōshi, pp. 138-142.

14 Ibid., pp. 31-32. 
historians have added to these data. Zhu Cishou lists all workshops of the Palace and the Central Government quoted in the 'Collected Statutes of the Song. ${ }^{15}$ In the Northern Song, these were the Palace Domestic Service (nei shisheng) and the Directorate for Imperial Manufactories (shaofu jian), which in total was made up of 144 sections and subsections. Some of these shared their workforce, but if duplications are subtracted, 105 individual units remain.

The institutions subordinate to the Palace Domestic Service were the Manufactory of the Rear Palace Quarters (houyuan zaozuo suo), the Brewery of the Court of National Granaries (sinong si du quyuan), the Water Mill Office (shuimo wu), and the Charcoal Yard (tanchang). The most important central government workshops and manufactories that belonged to the Directorate for Imperial Manufactories were the Office for Arts and Crafts (wensiyuan), where ceremonial and ornamental objects for court use were produced; the silk weaving manufactory Silk Brocade Office (lingjin yuan); and the Embroidery Office (wenxiu yuan). ${ }^{16}$ The numbers of artisans employed here may have ranged from a few dozen to in the hundreds, such as the six hundred in the Silk Brocade Office. ${ }^{17}$

At the same level as the Directorate for Imperial Manufactories and also concerned with craft production were the Directorate for Construction (jiangzuo jian), the Directorate for Armaments (junqi jian), and the Directorate of Waterways (dushui jian).

After the Jin conquered North China, the Song established imperial manufactories in their southern capital Lin'an. Institutions were slightly reshuffled, so that now the manufactories of the central government were all put under the control of the Ministry of Public Works. Zhu Cishou considers the four main sectors of craft production in the capital to have been armament, construction, printing, and the production of objects for official and court use. He suggests that immediately after the transfer to the south, the size of the manufactories was cut down, but in the course of time they expanded again..$^{18}$ State manufactories that were not stationed exclusively in the capital consisted of porcelain kilns, iron foundries, mints, armament and gunpowder manufactories, shipyards (which were of particular importance during the Southern Song), and paper manufactories.

15 Zhu Cishou, Zhongguo gudai gongye shi, p. 428 ff., referring to Song huiyao jigao 宋會要輯稿 (Editorial draft of the Collected Statutes of the Song), 'Zhiguan' (Official positions), chap. 29-1.

16 Founded in 1104 with 300 artisans; see Kuhn, Die Song-Dynastie, p. 121.

17 Gao Xuan, Songdai chuantong gongyi, p. 12.

18 Zhu Cishou, Zhongguo gudai gongye shi, p. 430. 
The non-state sector consisted of private workshops, individual craftspeople, and smaller-scale manufactories as well as workshops in Buddhist temples. Kuhn identifies, for instance, 21 private versus nine state manufactories for weaving silk with complicated patterns and points out that apart from these, an enormous number of smaller, private manufactories for plain silk weaving existed. ${ }^{19}$

A recent study by Qi Xia comes to the conclusion that in 1068, there were between 800,000 and one million artisan households (both private and in the service of the state), which in his calculation made up five to seven percent of all households. ${ }^{20}$ As to estimates of the figure of artisans in the service of the state during the Southern Song, Hu Xiaopeng estimates a total of 50,000 permanent positions and about 300,000 that were hired on a more temporary basis for work in mines, salt production, iron smelting, and other trades. ${ }^{21}$ On the basis of Angus Maddison's population estimates for the early Song (Table 6), the permanent workforce amounted to 0.09 percent of the entire population of 55 million and 0.05 percent of the population by the end of the dynasty. The entire workforce recruited ad hoc by the state was o.6 percent at the beginning and 0.35 percent at the end of the Song dynasty.

\section{Remuneration}

Work in government manufactories was remunerated and thus not 'real' corvée labour. However, there is evidence that it was not popular and was evaded if possible.

Reports of corruption point to officials that appropriated the production of artisans for their own use or disposal, as well as arbitrary wage cuts by officials, which were especially rampant during the Southern Song. ${ }^{22}$ In this light, the rule that 'whoever can double his workload will be especially rewarded'23 may not have been very attractive. ${ }^{24}$ However, in contrast to

19 Kuhn, Die Song-Dynastie, pp. 379-381.

20 Qi Xia, Songdaijingjishi, p. 726, also cited in Gao Xuan, 'Songdai chuantong gongyi', p. 14. For comparison: Wilfried Reininghaus, 'Stadt und Handwerk', p. 6, quotes the figure of ten to twelve percent as the percentage of artisans in the cities at the end of the Holy Roman Empire (1806).

21 Hu Xiaopeng, Zhongguo shougongye jingji tongshi, pp. 36-37.

22 Zhu Cishou, Zhongguo gudai gongye shi, p. 432.

23 Ibid., p. 432, quoting Jinshi cuibian 金石萃編, chap. 14, 'Xuanren houshan ling caishi ji' 宣 仁後山陵採石記.

24 Guo Daiheng, 'Yuanming yuan neigong zeli pingshu', p. 169, attaches a positive connotation to this phrase, pointing to the fact that the option to earn an efficiency wage under fair conditions 
this, the late Southern Song source Meng liang lu states that 'In the case of work obligations, although this is [the unpopular] 'consensual employment', if the authorities give out cash and rice for it, [and if] that wage is higher than that paid by private employers, then those who are obliged to work gladly will do so.' ${ }^{25}$

Song wage data for artisan labour are not systematically presented in government documents but appear in scattered sources. A remuneration of two sheng (ca. 1.17 liters) of rice or other grains per day plus a money allowance of between 10 and 100 cash coins seems to have been a standard wage for low-skill handicrafts but also for military and service sector occupations. Assuming an average daily consumption of about one liter of rice per person each day, ${ }^{26}$, such wages were adequate to feed one person but did not suffice to support families. The director of the arms manufactory 'Ten Thousand Perfections' complained in 1166 that the Ministry of Revenue gave out only 55 sheng (32.17 liters) of rice and 48 sheng (28.08 liters) of wheat per person per month plus a daily food allowance of 100 cash for the workers, and that this was not enough. ${ }^{27}$ Another example from ca. 1078 mentions daily wages for building walls and forts of 2 to 2.5 sheng (1.17 to 1.46 liters) of rice and 10 cash for pickled vegetables. ${ }^{28}$ In a state brewery, the pay was 300 copper cash per day for masters and 250 for unskilled helpers, with the option of a bonus for the master in case excellent wine was made. ${ }^{29} \mathrm{By}$ contrast, between 1063 and 1077, official salaries ranged from 300,000 to

was different from the Qing system, which did not reward artisans who surpassed their work quotas. However, in the Qing, there are records for bonuses for work in the commercial industry that exceeded the norms, for instance for the paper dyers in 1756 Suzhou. See Ming Qing Suzhou gongshangye beike ji, pp. 90-92.

25 Meng liang lu, chap. 13, p. 105 'Tuan hang' (Guilds and associations). The date of this source is disputed. It is given in characters of the hexagenarian cycle and could thus refer to '1274' at the end of the Southern Song as well as '1334' under the Mongol Yuan dynasty. Citing internal evidence, Umehara Kaoru, Mu ryō roku, vol. 3, pp. 374-375, plausibly argues that although the text deals only with the Southern Song and makes no reference to the Yuan rule, it must have been written in reminiscence of the splendour of the Southern Song capital. In view of the more rigid system of work recruitment under the Yuan, the Southern Song system may have seemed more lenient.

26 Xu Jianqing, Qingdai qianqi, p. 642, calculates one Qing dynasty sheng (1.035 liters) as a one-day ration.

27 Songshi, chap. 194, p. 4846.

28 Xu zizhi tongjian changbian (Continued Mirror for assistance in administration, Long version) 續資治通鑑長編, chap. 343 (Siku quanshu full text database).

29 Cited in Gao Xuan, 'Songdai chuantong gongyi', with reference to 'Regulations and precedents on brewing in the government breweries within the city' (Zaicheng jiuwu zaojiu zeli 在城酒務 造酒則例), p. 12. 
400,000 cash per month for the prime minister and 12,000 to 22,000 cash per month for county magistrates. ${ }^{30}$

In sum, one can discern little change over time in the basic labour institutions of the Song. Labour market conditions seem to have been flexible; the public and private sector were not made impermeable by laws or regulations. There are thus no indications of a transition of the craft production from state dominance to a preponderance of the private industries as in the subsequent dynasties.

\section{The Yuan System, 1279-1368}

At the outset of the dynasty, the Mongol way of recruiting artisans for the service of the state was very different from the Song practice. In a sense, artisans were specially favoured by the Mongol elite in all their conquered territories, since few skilled artisans existed in Mongolian society previous to their conquest of sedentary peoples, and these were traditionally held in high regard.$^{31}$ Therefore the Mongols showed strong interest in the artisans of the regions that had come under their domination. Artisans who specialized in armament production or produced luxury goods were spared from massacres in cities, taken to Mongolia, and presented to Mongolian nobles as personal servants..$^{32} \mathrm{~A}$ famous saying of the times is 'spare only the craftspeople' (weijiang de mian ).33 The dynastic history of the Yuan reports that in 1235, shortly after the conquest of the Jin dynasty, 720,000 'civilian artisans' or 'ordinary households and artisan households' were captured in the geographical areas corresponding to present-day Shandong, Hebei, and Shanxi. ${ }^{34}$ The term 'captives' has been subject to debate in the literature. Ju Qingyuan, for instance, refuted the view that these were actually slaves and

30 Deng, Premodern Chinese Economy, p. 302

$3^{1}$ Frederick Mote, 'Chinese society under Mongol rule', p. 654.

32 See Ritsuko Oshima, 'The Chiang-hu in the Yüan', p. 72, quoting from A.J. Boyle, The History of the World-Conqueror by 'Ala-ad-Din 'Ata-MalikJuvaini, translated from the text of Mirza Muhammad Qazvini, for the attack on Khorazum (i.e., Chorasan or Choresm) between 1220 and 1222. Juvaini mentions 100,000 artisans that were spared. When Genghis Khan conquered Samarkand in 1220, 30,000 artisans are said to have been taken to Mongolia; see Hu Xiaopeng, 'Yuandai de xiguan jianghu', p. 77.

33 It occurs in Yuanshi, chap. 163, in the biography of Zhang Xiongfei, p. 3819; chap. 119, in the biography of Muqali (Muhuali 木華黎), p. 2932, referring to the year 1216; in Liu Yin 劉因, Jingxiu ji 靜修集, chap. 21.

34 Yuanshi, chap. 123, biography of Kökö Buqa (Kuokuobuhua 闊闊不花), p. 3023. Oshima, “The Chiang-hu in the Yüan', p. 73, considers 民 (ordinary [households]) and 匠 (artisan [households]) 
held that designations such as 'captives' or 'captive slaves' (touxia, qukou) were 'merely linguistic habits of the historians'. Conversely, Zhu Cishou argues that the Mongols in the eleventh and twelfth centuries had entered the slave-holding period of their historical development and therefore treated these artisans as captive slaves. ${ }^{35}$ Declaring oneself to be an artisan may often have been a survival strategy. In a eulogy to a Han official in the service of the Mongols, it is related how in 1232, after the siege of the Southern capital of the Jin, he was summoned to assemble the artisans to take them north, and sent many more people than those who were actually skilled, thus saving innumerable lives. ${ }^{6}$ The dynastic history of the Yuan mentions that from 1275 onwards, more than three-hundred thousand artisans were summoned to the north after the Mongols had conquered the Southern Song. ${ }^{37}$ Zhu Cishou outlines three distinct phases of the use of artisans in the Yuan dynasty: at first, they were forced to serve as slaves; later, they were registered as regular and permanent 'official craftspeople'; finally, the system of 'official craftspeople' was changed to shorter, ad hoc labour shifts. $3^{8} \mathrm{He}$ argues that initially, the deported artisans stood at the mercy of their masters and were often mistreated. ${ }^{39}$ In the second phase, the artisans were formally registered by the state. They worked under strict control in the state manufactories and had little personal freedom. For instance, they had no choice in marriage, and inheritance of the trade was obligatory. However, guidelines for their remuneration were set up in 1291, and they were allowed to produce and sell anything produced beyond their obligations to the state. In the third phase, the government resorted more to summoning labour for specific short-term obligations. This change becomes perceptible in the designations for the corvée duties. In the early phases the concerned artisans were referred to as 'master-artisans' jiang, while the designation 'worker' gong dominates later. ${ }^{40}$

to be two separate categories, while Gao Rongsheng, 'Yuandai jianghu sanlun', p. 123, assumes that the 720,000 were only artisan households.

35 Chü Ch'ing-yüan, 'Government artisans of the Yüan Dynasty', p. 235/236; Zhu Cishou, Zhongguo gudai gongye shi, p. $554 \mathrm{ff}$.

36 Hu Zhiyu, Zishan da quan ji, chap. 16, pp. 1196-283, 'Dexing Yanjing Taiyuan renjiang daluheqi Wang gong shendao bei' (Epitaph for Mr. Wang, director of the artisans in Dexing, Yanjing, and Taiyuan). For a similar account in Baozhou (present-day Baoding in Hebei), cf. Ch'ü Ching-yüan, 'Government artisans of the Yüan Dynasty', p. 235.

37 Yuanshi, chap. 167, p. 3924.

38 Zhu Cishou, Zhongguo gudai gongye shi, p. $556 \mathrm{ff}$.

39 Ibid., pp. 556/557.

40 Ibid., p. 559; Gao Rongsheng, 'Yuandai jianghu sanlun', p. 124; Hu Xiaopeng, 'Yuandai de minjiang', pp. 66/67. 


\section{Registration and Size of the Official Workforce}

Artisans were first registered as distinct households by the Mongols in 1252 . The registers are no longer extant, but the dynastic history of the Yuan as well as other contemporary sources mention 'official artisan households', 'civilian [i.e. private] artisan households', and 'military artisan households'. Apart from these largest categories, other classifications also occur, such as 'salt making households', 'tea producing', iron smelting', 'mining', and 'gold panning' households.

The appended Table 2 shows a collection of references to numbers of artisans. These figures as well as the registration process and categories have been researched in detail, but opinions are still divided on how to interpret especially the larger figures. Apart from culling and complementing single references, calculatory methods have been applied, such as multiplying the officials in charge of artisans with the estimated number of artisans that were subordinate to them. With this method, Ch'ü Ching-yuan arrives at a figure of 300,000 official artisan households for the year 1272, excluding military artisan households but including 10,000 mangonel makers. ${ }^{41}$ More recent calculations take a broader perspective. Based on sample analyses of regional gazetteers, Hu Xiaopeng's statistics include military, salt making, wine and vinegar producing, and mining households..$^{42} \mathrm{His}$ result is more than one million households, seven percent of the entire households in 129o. This estimate is even doubled by Gao Rongsheng, who includes all available figures from historiography and arrives at two million households of official, private, and military artisans and (unskilled) workers. If one household is calculated to have five members, ${ }^{43}$ this amounts to ten million artisans and workers for the late thirteenth century, and thus no less than ten percent of the population.

\section{Remuneration}

Together with the census registration, a remunerative system was established. In 1288, it was stipulated that regularly registered persons above fifteen years of age should be given three dou of rice every month (25.08 liters) and half a jin (316 grams) of salt. Their family members should receive

41 Chü Ch'ing-yuan, 'Government artisans of the Yüan Dynasty', pp. 243-245. Mangonels are military machines for casting stones or other projectiles.

$42 \mathrm{Hu}$ Xiaopeng, Yuandai de xiguan jianghu, p. 79.

43 Gao Rongsheng, Yuandaijianghu sanlun, p. 124. 
2.5 dou (20.9 liters) for adults above fifteen years of age and 1.5 dou (12.54 liters) for young persons between five and fifteen years of age, while no rations were given for those under five. Those of servile status (qukou 驅 口) were to receive 12.54 liters for adults and 6.27 liters for young persons. ${ }^{44}$ However, there are reports of cases when these regulations were not applied. The official Wang Hui (1227-1304) stated that in two artisans' offices, people usually earned four dou (33.4 liters) of rice per month and half a jin (316 grams) of salt, but some were complaining that they had only received $2.5 \mathrm{dou}$ (20.9 liters) and no salt at all. ${ }^{45}$ Other reports show that artisans sometimes received 15 jin $(9.5 \mathrm{~kg})$ of wheat flour in addition to their rice rations. There is scattered evidence for monetary wages of 1.5 tael paper money per month plus clothing for summer and winter. Compared to the remuneration during the Song, this is lower in terms of food wages, but during the Yuan artisans' incomes were similar to soldiers' rations. ${ }^{46}$

\section{The Interface of Official and Private Employment}

Studies on the Yuan dynasty artisans concur that it was possible for government artisans to work for their own profit aside from their duties to the state. ${ }^{47}$ In the early Yuan, sources suggest that if 'civilian artisans' (minjiang 民匠) from private workshops were summoned to work obligations, this was done according to fixed rules. However, in the later phase of the Yuan dynasty, as the state artisan offices declined, ad hoc requisitions of labour increased. The case of the first emperor of the Ming, Zhu Yuanzhang (13281398), illustrates the problems caused by the inflexibility of the registration system. ${ }^{48}$ Zhu's grandfather had been registered as a member of a gold-panning household, but the family could neither produce the yearly amount of gold which they were obliged to present to the government nor change their household status and the obligations linked to it. They had to take to tenant farming in order to buy the gold on the market, but without sufficient income they eventually had to flee their home region in order to evade their fiscal obligations.

44 Tongzhitiaoge, chap. 13, p. 387 f., 'Regulations and precedents on provisions for work' ('Gongliang zeli' 工糧則例), p. 390, 'Precedents on adult and young persons' ('Da xiao kou li'大小口例).

45 Wang Hui, Qianjian ji, chap. 89, fol. 18a/b.

$46 \mathrm{Hu}$ Xiaopeng, Zhongguo shougongye jingji tongshi, p. 607.

47 Ch'ü Ching-yuan, 'Government artisans of the Yüan Dynasty', p. 243; Gao Rongsheng, 'Yuandai jianghu sanlun', p. 126.

48 Mote, 'Chinese society under Mongol rule', pp. 655/656. 
Although obviously the Yuan system of coerced labour could not be maintained with the same vigour during the entire course of the dynasty, textual evidence is too scarce to warrant the assumption that a private commercial sector unfolded as a result of this process, as it did in the Ming dynasty. Yet it is known that during the Yuan, important technological innovations occurred in the form of cotton ginning and spinning and that the government actively promoted cotton cultivation. ${ }^{49}$ Export ceramics were produced in the Fujian port city of Quanzhou with more or less the same intensity and involvement of households in the Yuan period as in the preceding Song period, in spite of the fact that the population had decreased by half. Billy So therefore assumes that double the amount of households, or around 14 percent of the prefectural population of Quanzhou, were engaged in full-time non-agricultural production by ca. $1290.5^{5}$ At least in this export-oriented craft branch in the port city with the highest export rates on China's coast, the craft sector was obviously not being repressed by the government nor overburdened by labour obligations.

\section{The Ming System, 1368-1644}

With only four classes - official, commoner, military, and artisan - the Ming system of household registration was more clear-cut than that of the Yuan. It was first devised in 1386 and provided that all registered artisans had to render service for three months every two years. The specific hardship of this system lay in the fact that this work was unpaid and that most service was required at the capitals, Nanjing until 1403, and thereafter at both Nanjing and Peking. Artisans who lived in remote areas had to travel far to fulfill their obligations. Two reforms were made in 1393 and 1454. In 1393, 62 craft branches were singled out for which service had to be rendered in one- to five-year shifts by 'shift artisans' (lunban jiang). Carpenters and tailors, for instance, were supposed to come to the capital every five years, while paperhangers, ${ }^{51}$ embroiderers, bow-makers, and printers had to take yearly turns. In 1454, this was once again changed to uniform four-year shifts. Other conditions applied for the registered artisans that lived near the capital, the so-called resident artisans (zhuzuojiang). From the reign of

49 Zurndorfer, 'The Resistant Fibre', p. 48.

50 So, Prosperity, Region, and Institutions, p. 196.

$5^{1}$ biaojiang 裱匠, artisans who paste paper to window frames or mount paintings or calligraphies on hanging scrolls. 
the Yongle emperor (1403-1424), they had to serve ten days every month. At first, the artisans were expected to work in the capital Nanjing. After the relocation of the capital to Peking, artisans from North and Central China were registered for service there, while those from the South and Southwest were expected in Nanjing, where a secondary capital with a downsized version of the Peking central government was maintained.

The number of registered artisans (see Table 4) varied from 232,089 people in 1393, of which 129,983 worked on shifts, to 289,000 in 1454 (240,00o for the two capitals, of which $25 \%$ for Nanjing and $75 \%$ for Peking). After the corvée obligations were changed to tax payments in 1562, 222,000 to 232,000 people remained as registered artisans within the respective household registration, which indicates that craft occupations remained inherited. Official Ming dynasty population figures are notoriously underreported, and therefore it is particularly difficult to define the percentage of the population that was registered as artisans. On the basis of Martin Heijdra's middle growth rates (see Table 7) for the years 1393 (90 million), 1454 (122 million), and 1562 (198 million), the percentage of registered artisans is 0.26 , 0.24 , and 0.12 percent respectively. ${ }^{22}$ Taking Angus Maddison's figures (see Table 6), the values are $0.34,0.33$, and 0.15 percent, calculated with the population figures for 1390, 1450, and 1560, which are slightly higher than Heijdra's. Nevertheless, in comparison to the Yuan, these numbers point to the much reduced profile of artisans in the permanent service of the government, which is certainly due to the greater availability of artisans from the labour market from the sixteenth century.

\section{Remuneration of Resident Artisans and Substitution of Work Service by Tax Payment}

This group's services were paid with rice provisions of generally three dou per month (29.61 liters), with an additional food allowance for days actually worked. ${ }^{33}$ Since the Zhengtong era (1436-1449), extra provisions of one jin (590 grams) of salt are mentioned. We find no reference to monetary wages in the 'Statutes of the Ming', but according to Zhu Cishou artisans received gratifications of one to two silver tael on special occasions, such as imperial enthronement.

$5^{2}$ For a critique of Heijdra's estimates, see Robert Marks, 'China's Population Size during the Ming and Qing', pp. 4-6.

53 Zhu Cishou, Zhongguo gudai gongye shi, p. 648. 
However, for obvious reasons, both types of registration and work obligations proved unpractical. In the course of the expanding market economy, the practice of labour service as a manner of tax payment in kind became obsolete. ${ }^{4}$ Since 1485 , artisans had the option to pay taxes rather than work for the state. The artisans from the south were supposed to pay $900 \mathrm{cash}$ per person per month, and those from the north 600 cash. ${ }^{5}$ In 1503 this was changed to a payment of 1.8 tael per shift or $45^{\circ}$ cash per year, and from $15^{62}$ on it was expressly forbidden to render labour service rather than to pay taxes. ${ }^{5}$ This did not mean that the state no longer employed artisans in permanent positions but that the work was now being paid in money and food provisions. ${ }^{57}$ The 1615 compilation Gongbu changku xu zhi ('What should be known about the factories and storehouses of the Ministry of Public Works') has detailed information on the activities and craft branches under official supervision as well as some wage data for administrators and artisans, and finally the tax income by the artisan shift tax from the provinces..$^{5^{8}}$

\section{Conclusion}

The three dynastic administrations all had a distinctive approach to allocating craft labour. The Song did not register craftspeople as such but made sure that the guilds organized the required labour force from their ranks. Artisans were hired in permanent positions or worked for shorter shifts in palace or government manufactories. Work for the state was remunerated in food rations and cash.

The Yuan used a complex system of registration in various household categories like 'official artisans', 'civilian artisans', 'military artisans', and several other specific occupations. Slavery or bound labour seems to have existed at least during the initial phases. Later artisans had more personal freedom, yet the artisan status remained hereditary. As a rule, work was remunerated in food provisions.

The registration of artisan households in the Ming was less complex than that of the Yuan. An elaborate system of work shifts, mainly at the capital, was tried out and changed several times. This type of shift labour was

54 Cf. Wang Shixin, 'State Workshops and the Handicraft Industry', pp. 65-80.

55 Da Ming huidian, chap. 189 , fol. 5 b.

56 Ibid., chap. 189 , fol. 8 a.

57 For details, see the section on the Longjiang shipyard in Chapter Six.

58 E.g. Gongbu changku xu zhi, chap. 3, fol. 1 ff., 'Nianli qianliang' (年例錢糧 'Yearly rules for money and provisions'), 1.5 tael per month for a printer. 
unpaid, but the artisans were fed. Resident artisans in the capital worked in more frequent shifts of ten days per month and were paid with food allowances. A hundred years after the system was initiated, tax payments were gradually substituted for obligatory work shifts. Thereafter artisans were hired and paid in food and monetary wages.

Population data for the periods in question, disputed as they are, might offer a partial explanation of some of the institutional changes. The population apparently shrank in periods of dynastic decline and the subsequent uprisings and warfare. The interpolations both by Maddison and by Heilig assume a decline from the Southern Song to the Yuan, and again at the end of the Ming; moreover, Maddison supposes that a marked decline occurred at the end of the Yuan. ${ }^{59} \mathrm{~A}$ decline in population may result either in greater coercion or, as in the case of Europe after the Black Death, in rising wages ${ }^{60}$ or other incentives for the scarcer labour force. Declining population figures may have been one factor behind the higher level of compulsion - or at least the attempt of allinclusive coverage of artisan workforce by registration - in the early Yuan and the early Ming. That the Qing government in its early phase officially abolished the artisan household registration, even if in actual practice it took longer for its last traces to be eliminated, may be an instance of the contrary measures taken in a similar situation - or at least of the political intention to do so. In the Ming, when the population and workforce increased and the commodity markets expanded, the artisan registration and corvée duties relaxed.

Both during the Yuan and the Ming, demand for skilled artisans was high in the initial phases of the dynasty, especially for building palaces, defensive structures, and infrastructure. That the government imposed stronger or lighter restrictions on the freedom of the workforce hinged also on its immediate demand for labour.

The economic situation under the Yuan is still disputed. The arguments have been elucidated in a volume of collected essays on the Song-Yuan-Ming transition. ${ }^{61}$ The issue at stake is whether the Yuan was a dark age of decline and a turning point that ended the early phase of the Tang-Song commercialization and early modernity, as portrayed by the Japanese historian Naitō Kōnan, or whether the trajectory between the Song and the Ming was rather an evolutionary phase that led to the second wave of commercialization

59 Maddison, Chinese economic performance, p. 26, Figure 1.1; Heilig, 'IIASA Data-Population: China's Population Growth, A.D. 0-2050'.

60 Routt, David, 'The Economic Impact of the Black Death'.

61 Smith and von Glahn, The Song-Yuan-Ming Transition, especially p. 2, which explains that the Yuan are still considered by many scholars as 'terra incognita' and the 'divide between mid- and late imperial China'. 
starting in the mid-sixteenth century. The latter is the perception of the authors of The Song-Yuan-Ming transition, and most decidedly Li Bozhong. ${ }^{62}$ Depending on the perspective taken and on the research object, the outlook on the period between the tenth and the sixteenth centuries will differ. Those authors who look at the political economy of these eras, as Liu Guanglin did with the fiscal administration of the Song, Ming, and Qing dynasties, ${ }^{63}$ find more differences and ruptures between these dynasties, while from the perspective of agricultural development or from the regional elites based outside the power centres, the evolutionary tendencies will seem stronger. Timothy Brook has pointed to continuities between the Yuan and the Ming in the political and economic field, such as the conflicting legacies of autocracy and commercialization. ${ }^{6}$ Yet even Brook does not explain the arrangements for artisans in the service of the state in those two dynasties in terms of evolution but rather points to the discontinuity between the great detail of household registration in as many as eighty-three different groups in the Yuan and the return to the simplifying fourfold structure in the Ming. ${ }^{65}$

Artisan registration and its gradual dissolution belong to the field of political economy, and consequently three distinct ways of organization emerge that are not directly related in a historical sense. The Yuan system was not an inheritance from the Song dynasty but shows the characteristics of a steppe and nomad regime with its initial preference for particular artisan skills (most notably in military and luxury production) and reservations towards agriculture. Military vigour and conquest played a central role in the political self-understanding of the Mongols, and traditions of unfree labour persisted.

The figures of official artisans in relation to the entire population also show that, numerically, direct state organization of the crafts was receding. From 350,00o permanent and temporary artisans with work obligations in the Song to two million registered artisan households in the Yuan, the figure of 280,000 registered artisans in the early Ming clearly indicates the waning engagement of the state. In terms of population figures, the artisan workforce in the service of the state in the Northern Song was at the most at 0.6 percent of the entire population; in the Yuan (1290), seven percent of the entire households were registered for actual or potential service for the

62 Ibid., p. 6; Li Bozhong, 'Was There a 'Fourteenth-Century Turning Point'?', pp. 135-175, p. 175.

63 Liu Guanglin, Wrestling for Power and The Chinese Market Economy.

64 Brook, The Troubled Empire, pp. 1 and 22, where the continuities of autocracy and commercialization are linked up to the Song.

65 Ibid., p. 147. 
state; in the Ming, depending on the population estimates assumed, these figures were between 0.26 and 0.15 percent.

The evidence does not warrant the conclusion that under the Song or the Yuan system, the initially strong state organization weakened in the course of the dynasty. This is the case, however, for the Ming system, where the private sector started to supersede the state sector in scope and size. However, its characteristic transformation of labour obligations into tax payments was not unique to the Ming dynasty. This had also occasionally been implemented under dynastic rulers in the first millennium A.D. In the Ming, the private and state sector became largely permeable after the mid-sixteenth century.

\section{Appendix}

Table 1 Artisans and workers in the Song dynasty state workshops, manufactories, and mines

\begin{tabular}{|c|c|c|c|}
\hline Time & Institution & $\begin{array}{l}\text { Workforce } \\
\text { (persons) }\end{array}$ & Specialization \\
\hline \multirow[t]{2}{*}{$\begin{array}{l}\text { Jingkang reign, } \\
1126-1127\end{array}$} & $\begin{array}{l}\text { Imperial Arsenal, Armament produc- } \\
\text { tion sites, Military Artisans of a Myriad } \\
\text { Perfections (Yuqian junqi suo 御前 } \\
\text { 軍器所, Junqi jian 軍器監, Wanquan } \\
\text { junjiang 萬全軍匠) }\end{array}$ & 3,700 & Military artisans \\
\hline & $\begin{array}{l}\text { Imperial arsenal, Eastern and Western } \\
\text { Workshops (Yuqian junqi suo 御前軍 } \\
\text { 器所, Dong xi zuofang 東西作坊) }\end{array}$ & 5,000 & $\begin{array}{l}\text { Military artisans; } \\
\text { construction } \\
\text { workers? }\end{array}$ \\
\hline \multirow{2}{*}{$\begin{array}{l}\text { ca. late } 12^{\text {th }} / \\
\text { early } 13^{\text {th }} \\
\text { century }\end{array}$} & $\begin{array}{l}\text { Wanquan zhihui萬全指揮 (Myriad } \\
\text { Perfections command) }\end{array}$ & 5,700 & Military artisans \\
\hline & $\begin{array}{l}\text { Military workshops in the provinces } \\
\text { 諸州作院 }\end{array}$ & 1,000 & Military artisans \\
\hline $\begin{array}{l}1334 \text { (retrospec- } \\
\text { tion to late } 13^{\text {th }} \\
\text { century) }\end{array}$ & $\begin{array}{l}\text { Paper manufacturing for paper money } \\
\text { 造會紙局 }\end{array}$ & 1,200 & Paper makers \\
\hline South Song? & $\begin{array}{l}\text { Shu jinyuan 蜀錦院 } \\
\text { Brocade manufacturing in Sichuan } \\
\text { (Chengdu) }\end{array}$ & 500 & $\begin{array}{l}\text { Military artisans/ } \\
\text { weavers }\end{array}$ \\
\hline $13^{\text {th }}$ century & $\begin{array}{l}\text { Zhanchun 䕤春, Tieqian jian 鉄錢監. } \\
\text { (Iron and lead workshop) }\end{array}$ & $\begin{array}{l}300 \\
\text { Each day }\end{array}$ & $\begin{array}{l}\text { iron and copper } \\
\text { smelters }\end{array}$ \\
\hline 1078 & $\begin{array}{l}\text { Iron foundries at Xuzhou 徐州三十 } \\
\text { 六冶 }\end{array}$ & $\begin{array}{l}36 \text { foundries, } \\
100 \text { workers } \\
\text { each }\end{array}$ & iron smelters \\
\hline$?$ & $\begin{array}{l}\text { Coloured metal mining 五金雜產 at } \\
\text { Shaozhou 韶州 }\end{array}$ & 10,000 & $\begin{array}{l}\text { miners (and } \\
\text { smelters?) }\end{array}$ \\
\hline
\end{tabular}




\begin{tabular}{llll}
\hline Time & Institution & $\begin{array}{l}\text { Workforce } \\
\text { (persons) }\end{array}$ & Specialization \\
\hline $\begin{array}{l}\text { early } 13^{\text {th }} \\
\text { century }\end{array}$ & Iron foundry 鉄冶 & 500 & $\begin{array}{l}\text { iron smelters and } \\
\text { casters }\end{array}$ \\
$\begin{array}{l}12^{\text {th }} \text { century } \\
\text { Ironsmiths in one military prefecture } \\
\text { (jun } \text { 軍) }\end{array}$ & 18,000 & $\begin{array}{l}\text { Arms manufactur- } \\
\text { ers: ironsmiths }\end{array}$ \\
\hline
\end{tabular}

Source: Ju Qingyuan, Tō Sō kōgyōshi, p. 31-32.

Table 2 Yuan dynasty artisans and workers in state workshops, manufactories, and mines

\begin{tabular}{|c|c|c|}
\hline & Artisans and institutions & Figures (persons) \\
\hline 1276 & $\begin{array}{l}\text { 籍江南民為工匠 } \\
\text { Registration of Jiangnan population: 300,000 ordinary } \\
\text { craft households }\end{array}$ & $\begin{array}{l}300,000 \text { 工匠 } \\
\text { (workers and } \\
\text { artisans) }\end{array}$ \\
\hline 1284 & $\begin{array}{l}\text { Among the } 300,000 \text { craft households in Jiangnan, } \\
\text { 190,000 should be re-registered as ordinary households } \\
\text { (minhu民戶) because they had no specific skills }\end{array}$ & $\begin{array}{l}\text { 110,000工匠 } \\
\text { (workers and } \\
\text { artisans) }\end{array}$ \\
\hline 1288 & $\begin{array}{l}\text { Gansu and Shaanxi military colony land for } 1,500 \\
\text { artisans }\end{array}$ & $\begin{array}{l}\text { 1,500工匠(workers } \\
\text { and artisans) }\end{array}$ \\
\hline 1310 & $\begin{array}{l}\text { For building the temple Wutai si 五台寺, 1,400 artisans } \\
\text { and 3,500 soldiers were recruited }\end{array}$ & $\begin{array}{l}\text { 1,400工匠(workers } \\
\text { and artisans) }\end{array}$ \\
\hline \multirow[t]{2}{*}{1236} & Minjiang (civilian artisans) & $\begin{array}{l}\text { 720,000 民匠 } \\
\text { (civilian artisans) }\end{array}$ \\
\hline & $\begin{array}{l}4 \text { kilns at Dadu 大都四㶻場, } 300 \text { artisans and labourers for } \\
\text { the production of glazed tiles (liuli zhuanwa 琉璃磚瓦) }\end{array}$ & $\begin{array}{l}300 \text { 匠夫 } \\
\text { [artisans and } \\
\text { (unskilled) workers] }\end{array}$ \\
\hline 1261 & $\begin{array}{l}\text { Xiunei si 修内司 (Palace Maintenance Office) } 140 \text { offices, } \\
450 \text { renjiang 人匠 (ordinary artisans) for construction }\end{array}$ & $\begin{array}{l}450 \text { 人匠(civilian } \\
\text { artisans) }\end{array}$ \\
\hline $1271-1284$ & Number of craftspeople in Xiunei si enlarged & $\begin{array}{l}\text { 1,272工匠(workers } \\
\text { and artisans) }\end{array}$ \\
\hline $1267 / 1274$ & Caishi ju 采石局(Quarries) & $\begin{array}{l}2,000+\text { 夫 } \\
\text { (unskilled workers) }\end{array}$ \\
\hline \multirow[t]{3}{*}{1284} & $\begin{array}{l}\text { Dyeing and weaving office at Daming 大名織染雜造兩 } \\
\text { 提舉司 }\end{array}$ & $\begin{array}{l}\text { 1,540人匠 (civilian } \\
\text { artisans) }\end{array}$ \\
\hline & $\begin{array}{l}\text { 沜天下之工, 聚之京師, 分類置向, 以考其程度, 而給之 } \\
\text { 食, 復其戶使得以專于其藝 The artisans in the empire } \\
\text { were inspected, they were assembled in the capital } \\
\text { and categorized, and their skills were tested and they } \\
\text { were given food and were registered according to their } \\
\text { specializations. }\end{array}$ & \\
\hline & $\begin{array}{l}\text { Child/juvenile artisans, male and female, were recruited } \\
\text { and sent to Hongzhou 收天下童男童女及工匠, 置局弘州 } \\
\text { (今河北陽原縣). Thus, there were } 300 \text { silk weavers織金 } \\
\text { 綺紋工in Hongzhou and } 300 \text { wool weavers 織毛褐工 in } \\
\text { Bianliang/Kaifeng. }\end{array}$ & $\begin{array}{l}\text { 300+戶 } \\
\text { (households) } \\
\text { 300+戶 } \\
\text { (households) }\end{array}$ \\
\hline
\end{tabular}




\begin{tabular}{|c|c|}
\hline Artisans and institutions & Figures (persons) \\
\hline Dadu 大都 and Suzhou 蘇州: 600+ hunters and artisans & $\begin{array}{l}\text { 打捕戶及民匠 } \\
600+\text { (artisans and } \\
\text { worker households) }\end{array}$ \\
\hline Zhiying si 祗應司: Construction of palaces for princes & $\begin{array}{l}\text { 700工匠 (artisans } \\
\text { and workers) }\end{array}$ \\
\hline Rhinoceros horn and ivory craftshops 犀象牙局 & $\begin{array}{l}\text { 150匠戶 (artisan } \\
\text { households) }\end{array}$ \\
\hline Foresters of Dadu 大都采山提領所 & $\begin{array}{l}163 \text { 夫匠 (unskilled } \\
\text { workers and } \\
\text { artisans) }\end{array}$ \\
\hline Dianpi ju 甸皮句 (Office for hides) & 30+匠 (artisans) \\
\hline Baoding weaving and dyeing office保定織染局 & $\begin{array}{l}\text { 101戶匠 (artisan } \\
\text { households) }\end{array}$ \\
\hline $\begin{array}{l}\text { Guanling suilu zhuse minjiang daluhuachi guanguan 管領 } \\
\text { 隨路諸色民匠達魯花赤管官 (Overseer of the Supervi- } \\
\text { sory Directorate of Artisans in the Various Routes, i.e. } \\
\text { Provinces) }\end{array}$ & $\begin{array}{l}\text { 1,525戶民匠 } \\
\text { (civilian artisan } \\
\text { households) }\end{array}$ \\
\hline Dadu minjiang 大都民匠 (Civilian artisans in Dadu) & $\begin{array}{l}\text { 202民匠 (civilian } \\
\text { artisans) }\end{array}$ \\
\hline $\begin{array}{l}\text { Zhuozhou chengjin ju renjiang 溷州成錦局人匠 } \\
\text { Brocade weavers in Zhuozhou }\end{array}$ & $\begin{array}{l}\text { 102戶人匠 (civilian } \\
\text { artisan households) }\end{array}$ \\
\hline
\end{tabular}

Source: Yang Zihui, Zhongguo lidai renkou tongji ziliao yanjiu, p. $813 \mathrm{ff}$.

Table 3 Ming dynasty work obligation shifts of builders according to the 1393 regulations

\begin{tabular}{llcl}
\hline Craft branch & & Registered persons & Interval \\
\hline Carpenters & 木匠 & 33,928 & five years \\
Sawyers & 鋸匠 & 9,679 & four years \\
Tilers and bricklayers & 瓦匠 & 7,590 & four years \\
Painters and lacquerers & 油漆匠 & 5,137 & four years \\
Earth pounders & 土工匠 & 1,376 & three years \\
Scaffolders & 搭材匠 & 1,112 & three years \\
Stone masons & 石匠 & 6,017 & two years \\
\hline
\end{tabular}

Sources: Ruitenbeek, Carpentry and Building, p. 17, and Da Ming huidian, chap. 189, fol. 1a-5a.

Table 4 Registered artisans in the Ming dynasty

\begin{tabular}{llll}
\hline Source & Time & Artisans & Figures (persons) \\
\hline $\begin{array}{l}\text { Ming huidian } \\
\text { chap. 189, fol. 1b }\end{array}$ & 1393 & Total & 232,089 \\
& & Registered shift obligation artisans & 129,983
\end{tabular}




\begin{tabular}{llll}
\hline Source & Time & Artisans & Figures (persons) \\
\hline $\begin{array}{l}\text { Zhengtong shilu } \\
\text { chap. 153 }\end{array}$ & 1454 & Total & $289,000+$ \\
& & Labour obligations for Nanjing & 58,000 \\
& & $\begin{array}{l}\text { Labour obligations for Beijing } \\
\text { Net }\end{array}$ & 182,000 \\
& & Tax obligations for Beijing & 142,480 \\
$\begin{array}{l}\text { Ming huidian } \\
\text { chap. 198, fol. 8a }\end{array}$ & 1562 & Tax obligations for Nanjing & 59,695 \\
$\begin{array}{l}\text { Ming huidian } \\
\text { chap. 208 }\end{array}$ & & + missing obligations for Nanjing & $20,000-30,000$ \\
& & Total & $222,181-232,181$ \\
\hline
\end{tabular}

Sources: Zhu Cishou, Zhongguo gudai gongye shi, p. 643 ff. and Da Ming huidian, chap. 189.

Table 5 Ming dynasty Peking resident artisan positions in 1567

\begin{tabular}{|c|c|c|c|}
\hline Institution & & $\begin{array}{l}\text { Overseers } \\
\text { of artisans/ } \\
\text { officials }\end{array}$ & $\begin{array}{l}\text { Military and } \\
\text { civilian artisans/ } \\
\text { persons }\end{array}$ \\
\hline Directorate of Ceremonial & 司禮監 & 433 & 1,383 \\
\hline Directorate of Palace Eunuchs & 内官監 & 480 & 1,883 \\
\hline Directorate of Imperial Regalia & 司設監 & 33 & 1,437 \\
\hline Directorate of Imperial Accoutrements ${ }^{1}$ & 御用監 & 40 & 2,755 \\
\hline Directorate for Credentials ${ }^{2}$ & 印綬監 & & 19 \\
\hline Directorate of Imperial Apparel & 尚衣監 & 42 & 654 \\
\hline Directorate of the Imperial Horses & 御馬監 & 11 & 305 \\
\hline Palace Weaving and Dyeing Office & 内織染局 & & 1,343 \\
\hline Silversmith Office & 銀作局 & 23 & 166 \\
\hline Palace Armory & 兵仗局 & 6 & 1,781 \\
\hline Cap and Hat Office & 巾帽局 & & 498 \\
\hline Sewing Office & 針工局 & 1 & 359 \\
\hline Paper Office & 寶鈔司 & & 624 \\
\hline Silver Storehouse & 司銀庫 & & 15 \\
\hline Storehouse Administration & 内承運庫 & & 359 \\
\hline Palace Granary ${ }^{3}$ & 供應庫 & 4 & 259 \\
\hline Firewood Office ${ }^{4}$ & 惜薪司 & & 18 \\
\hline Condiments Service 5 & 酒醋麵局 & & 169 \\
\hline Military Kitchen, Directorate of Palace & 尚膳監 & & 693 \\
\hline Delicacies & 軍廚 & & \\
\hline Total & & 1,073 & 14,740 \\
\hline
\end{tabular}

Sources: Da Ming huidian, chap. 189 and Sun Jian, Beijing gudai jingji shi, p. 185.

${ }^{1}$ Hucker, A Dictionary of Official Titles, No. 8213: This office was responsible for preparing fine wood and ivory object for the Emperor's use and for presenting memorials for imperial attention that were submitted by the officialdom. 
${ }^{2}$ Hucker, A Dictionary of Official Titles, No. 7994: in cooperation with the Directorate of Palace Seals (shangbao jian) managed the seals and tallies with which the imperial documents were authenticated.

${ }^{3}$ Gugong cidian, p. 131.

${ }^{4} \mathrm{lbid}$.

${ }^{5}$ Hucker, A Dictionary of Official Titles, No. 1319: prepared sauces and other condiments for palace use.

Table 6 Estimated Chinese population figures, 960 to 1640

\begin{tabular}{|c|c|}
\hline Year & Million persons \\
\hline 960 & 55 \\
\hline 1280 & 100 \\
\hline 1380 & 68 \\
\hline 1390 & 69 \\
\hline 1400 & 72 \\
\hline 1410 & 71 \\
\hline 1420 & 73 \\
\hline 1430 & 77 \\
\hline 1440 & 82 \\
\hline 1450 & 88 \\
\hline 1460 & 93 \\
\hline 1470 & 104 \\
\hline 1480 & 116 \\
\hline 1490 & 98 \\
\hline 1500 & 103 \\
\hline 1510 & 117 \\
\hline 1520 & 133 \\
\hline 1530 & 139 \\
\hline 1540 & 144 \\
\hline 1550 & 146 \\
\hline 1560 & 151 \\
\hline 1570 & 155 \\
\hline 1580 & 162 \\
\hline 1590 & 162 \\
\hline 1600 & 160 \\
\hline 1610 & 153 \\
\hline 1620 & 145 \\
\hline 1630 & 138 \\
\hline 1640 & 130 \\
\hline
\end{tabular}

Source: Maddison, Chinese Economic Performance in the Long Run, p. 169, Table D.1. 
Table 7 A variant estimate for population figures in the Ming and the early Qing (million persons)

\begin{tabular}{|c|c|c|c|c|}
\hline & 1380 & 1500 & 1600 & 1650 \\
\hline High growth rates & 85 & 175 & 289 & 353 \\
\hline \multicolumn{5}{|l|}{ 1380-1500: $0.6 \%$} \\
\hline \multicolumn{5}{|l|}{ 1500-1600: $0.5 \%$} \\
\hline \multicolumn{5}{|l|}{ 1600-1650: 0.4\% } \\
\hline Middle growth rates & 85 & 155 & 231 & 268 \\
\hline \multicolumn{5}{|l|}{ 1380-1500: $0.5 \%$} \\
\hline \multicolumn{5}{|l|}{ 1500-1600: $0.4 \%$} \\
\hline \multicolumn{5}{|l|}{ 1600-1650: $0.3 \%$} \\
\hline Low growth rates & 85 & 137 & 185 & 204 \\
\hline \multicolumn{5}{|l|}{ 1380-1500: $0.4 \%$} \\
\hline \multicolumn{5}{|l|}{ 1500-1600: $0.3 \%$} \\
\hline 1600-1650: $0.2 \%$ & & & & \\
\hline
\end{tabular}

Source: Heijdra, 'The Socio-Economic Development of Rural China During the Ming', p. 438. Heijdra assumes that the middle or high growth rates are more probable than the low ones. 